\title{
PELAKSANAAN RENCANA PEMBELAJARAN SEMESTER DALAM PROSES PEMBELAJARAN DI PERGURUAN TINGGI
}

\author{
${ }^{1}$ Bintang Petrus Sitepu \& ${ }^{2}$ Ika Lestari \\ e-mail: pietbarung12@gmail.com \\ Universitas Negeri Jakarta
}

Jalan Rawamangun Muka, Jakarta Timur 13220

\begin{abstract}
Abstrak: Kurikulum pendidikan tinggi tertuang di dalam Rencana Pembelajaran Semester (RPS) menurut Permenristekdikti No. 44 Tahun 2015. RPS hendaknya mengikat dosen dan mahasiswa ke dalam kontrak belajar/kuliah sehingga perlu dilakukan pengawasan dan pemeriksaan terhadap kualitas RPS yang dibuat oleh dosen. Tujuan penelitian ini melakukan survei dan pengamatan di lingkungan Fakultas Ilmu Pendidikan Universitas Negeri Jakarta sehingga memperoleh data dan informasi yang lengkap dan akurat. Mengacu pada tujuannya, penelitian ini termasuk penelitian deskriptif evaluatif dengan menggunakan data kualitatif dan kuantitatif. Teknik pengumpulan data menggunakan kuesioner, wawancara, dan studi dokumen. Data diolah dan dianalisis dengan menggunakan statistik sederhana dan secara deskriptif. Penelitian dilakukan di Fakultas Ilmu Pendidikan pada tahun 2017. Hasil penelitian berupa laporan tentang persentase dosen membuat RPS, keterlibatan mahasiswa dalam menyempurnakan RPS, kebermanfaatan RPS bagi mahasiswa, pengetahuan mahasiswa terhadap pokok bahasan dan tujuan pembelajaran mata kuliah, serta rujukan yang digunakan. Rekomendasi selanjutnya dapat dilakukan evaluasi terhadap isi RPS yang dibuat oleh dosen sesuai Permenristekdikti No 44 Tahun 2015.
\end{abstract}

Kata-kata kunci: rencana pembelajaran semester, standar proses, proses pembelajaran

\section{IMPLEMENTATION OF SEMESTER LEARNING PLAN IN LEARNING PROCESS AT UNIVERSITY}

\begin{abstract}
Higher-education curriculum is contained in Semester Learning Plan (RPS) as stated in Permenristekdikti No. 44 of 2015. RPS should bind lecturers and students into the contract of study / college so that it needs to be supervised and examination of the quality of RPS made by lecturers. The purpose of this study is to conduct surveys and observations within the Fakultas Ilmu Pendidikan, Universitas Negeri Jakarta to obtain complete and accurate data and information. Referring to its purpose, this research includes descriptive evaluative research using qualitative and quantitative data. Data collection techniques used questionnaires, interviews, and document studies. Data is processed and analyzed using simple and descriptive statistics. The research was conducted in the Fakultas Ilmu Pendidikan, Universitas Negeri Jakarta in 2017. The results from the research are the percentage of lecturers to make RPS, student involvement in refining RPS, RPS utilization for students, students' knowledge on the subject and learning objectives during the course, and the references used. Further recommendations can be evaluated on the content of RPS made by lecturers in accordance with Permenristekdikti No. 44 of 2015.
\end{abstract}

Keywords: semester learning plan, process standard, learning process

\section{PENDAHULUAN}

Pendidikan di setiap jenjang dan jenis diselenggarakan berdasarkan kurikulum yang ditetapkan dalam standar isi pendidikan nasional. Dalam Peraturan Menteri Riset, Teknologi dan Pendidikan Tinggi (Permenristekdikti), No. 44 Tahun 2015, tentang Standar Nasional Pendidikan Tinggi, kurikulum dimaknai sebagai "Seperangkat rencana dan pengaturan mengenai capaian pembelajaran lulusan, bahan kajian, proses, dan penilaian yang digunakan sebagai pedoman penyelenggaraan program studi". Selanjutnya, kurikulum pendidikan tinggi dikembangkan menjadi Rencana Pembelajaran Semester (RPS). Dalam pelaksanaan perkuliahan, dosen menyusun Satuan Acara Perkuliahan (SAP) 
berpedoman pada RPS mata kuliah. Melalui pengembangan dan pelaksanaan kurikulum yang demikian, diharapkan kompetensi dalam standar kompetensi kelulusan dapat tercapai.

Dalam kurikulum pendidikan tinggi berbasis Kerangka Kompetensi Nasional Indonesia (KKNI), kompetensi dirumuskan mulai dalam bentuk deskripsi generik untuk setiap level, deskripsi spesifik prodi, learning outcomes lulusan prodi, kurikulum prodi (Daftar Deskripsi dan Bobot SKS Mata kuliah), rencana pembelajaran semester (mata kuliah), dan satuan acara perkuliahan. Proses pembelajaran pada program studi untuk memperoleh capaian pembelajaran lulusan didasarkan pada standar proses pembelajaran yang ditetapkan dalam Bagian Keempat, Permenristekdikti No. 44 Tahun 2015. Standar proses pembelajaran yang dimaksud mencakup (a) karakteristik proses pembelajaran, (b) perencanaan proses pembelajaran, (c) pelaksanaan proses pembelajaran, dan (d) beban belajar mahasiswa.

Perencanaan proses pembelajaran disusun untuk setiap mata kuliah dan disajikan dalam RPS atau istilah lain yang ditetapkan dan dikembangkan oleh dosen secara mandiri atau bersama dalam kelompok keahlian suatu bidang ilmu pengetahuan dan/atau teknologi dalam program studi. Istilah lain yang dimaksud antara lain Rencana Program Kegiatan Pembelajaran Semester (RPKPS), Pedoman Perkuliahan, atau Kontrak Kuliah. Dalam penelitian ini, istilah yang dipakai adalah RPS sesuai dengan Permenristekdikti No. 44 Tahun 2015.

Dosen menyusun RPS mengacu pada deskripsi spesifik prodi dan outcomes lulusan prodi, serta kurikulum prodi. Pasal 12 Ayat (1) Permenristekdikti No. 44 Tahun 2015 menyebutkan, proses pembelajaran didasarkan pada RPS yang disusun untuk setiap mata kuliah. Lebih lanjut, Pasal 12 Ayat (3) menyebutkan, RPS paling sedikit memuat (1) nama program studi, nama dan kode mata kuliah, semester, sks, nama dosen pengampu; (2) capaian pembelajaran lulusan yang dibebankan pada mata kuliah; (3) kemampuan akhir yang direncanakan pada tiap tahap pembelajaran untuk memenuhi capaian pembelajaran lulusan; (4) bahan kajian yang terkait dengan kemampuan yang akan dicapai; (5) metode pembelajaran; (6) pengalaman belajar mahasiswa yang diwujudkan dalam bentuk deskripsi tugas yang harus dikerjakan mahasiswa selama satu semester; (7) kriteria, indikator, dan bobot penilaian; dan (8) daftar referensi yang digunakan.

Setiap dosen menyusun RPS untuk mata kuliah yang diampunya. RPS berisi setidak-tidaknya manfaat mata kuliah, deskripsi mata kuliah, tujuan perkuliahan, materi/pokok bahasan, strategi perkuliahan/ pembelajaran, daftar rujukan/referensi, tugas, kriteria penilaian, serta jadwal perkuliahan dengan topik bahasan dan bahan bacaan. RPS ini bermanfaat kepada dosen dalam (a) merancang perkuliahan secara holistik dan sistematis, (b) menyusun SAP, (c) mengevaluasi dan meningkatkan mutu kegiatan perkuliahan yang sedang berlangsung, dan (d) merancang perkuliahan semester berikutnya. Bagi mahasiswa, RPS memberikan informasi tentang (a) mata kuliah secara utuh, (b) beban tugas dan tagihan mata kuliah, (c) gaya belajar yang sesuai, dan (d) sistem penilaian hasil belajar. Untuk kepentingan lain RPS bermanfaat sebagai (a) acuan bagi dosen lain ketika harus menggantikan dosen pemangku kuliah yang bersangkutan, (b) dokumen acuan untuk keperluan monitoring pelaksanaan perkuliahan, dan (c) dokumen pendukung ketika dilakukan akreditasi program studi atau lembaga.

Dalam standar nasional pendidikan tinggi, tidak ada ketentuan yang menyebutkan rancangan RPS harus dibicarakan dan disepakati dengan mahasiswa. Akan tetapi, mengingat pendekatan perkuliahan di perguruan tinggi berpusat kepada kepentingan mahasiswa dan menggunakan pendekatan pembelajaran orang dewasa (andragogi), sewajarnya konsep/rancangan RPS dibicarakan dan disepakati dengan mahasiswa. Dalam pembahasan konsep RPS, dosen menjelaskan dan meminta pendapat mahasiswa khususnya mengenai tujuan perkuliahan, materi/pokok bahasan, strategi perkuliahan, daftar rujukan/referensi, dan kriteria penilaian. Dengan berperan serta dalam menyusun RPS, mahasiswa lebih menghayati rencana perkuliahan, merasa keinginan dan kebutuhan terwadahi sehingga memotivasi untuk belajar dan memiliki tanggung jawab dalam mencapai tujuan mata kuliah.

Untuk meningkatkan dan menjaga mutu pendidikan tinggi, Pemerintah menetapkan Standar Nasional Pendidikan Tinggi (SNPT) yang merupakan satuan standar meliputi Standar Nasional Pendidikan (SNP), ditambah dengan Standar Nasional Penelitian, dan Standar Nasional Pengabdian kepada Masyarakat. SNP meliputi (a) standar kompetensi lulusan, (b) standar isi pembelajaran, (c) standar proses pembelajaran, (d) standar penilaian pembelajaran, (e) standar dosen dan tenaga kependidikan, (f) standar sarana dan prasarana pembelajaran, (g) standar pengelolaan pembelajaran, dan (h) standar pembiayaan pembelajaran.

Standar proses pembelajaran merupakan kriteria minimal tentang pelaksanaan pembelajaran 
pada program studi untuk memperoleh capaian pembelajaran lulusan. Standar proses mencakup karakteristik, perencanaan, dan pelaksanaan pembelajaran, serta beban belajar mahasiswa. Perencanaan proses pembelajaran untuk setiap mata kuliah disusun dan disajikan dalam bentuk Rencana Pembelajaran Semester (RPS) atau istilah lain yang wajib ditinjau dan disesuaikan secara berkala dengan perkembangan ilmu pengetahuan dan teknologi.

RPS adalah proses pembelajaran dalam setiap mata kuliah yang disusun dan dikembangkan oleh dosen yang bersangkutan secara mandiri atau bersama dalam kelompok keahlian suatu bidang ilmu pengetahuan dan/atau teknologi/seni dalam program studi (Permenristekdikti No. 44 Tahun 2015, Pasal 12 Ayat 2). RPS dijadikan acuan oleh dosen dan mahasiswa dalam proses pembelajaran/kegiatan perkuliahan dalam satu semester.

Dilihat dari fungsi dan pemanfaatannya, RPS hendaknya dapat dijadikan sebagai kontrak belajar/ kuliah yang mengikat mahasiswa dan dosen. Boak (1998: ix) mengatakan sebagai kontrak belajar, RPS merupakan kesepakatan formal antara pemelajar (mahasiswa) dan pembelajar (dosen). Penyusunan RPS mengikutsertakan dan atas persetujuan mahasiswa. Dengan demikian, RPS merupakan hasil kesepakatan bersama secara tertulis dan formal antara mahasiswa dan dosen tentang apa yang akan dipelajari dan bagaimana proses belajar itu akan diukur. Lebih lanjut, Boak (1998: 1-5 ) mengemukakan RPS sebagai kontrak perkuliahan yang berciri fleksibel dan fokus pada pencapaian tujuan pembelajaran memberikan manfaat: (a) pembelajaran menjadi lebih relevan, (b) mahasiswa berperan serta dalam penyusunan dan penetapan RPS, (c) RPS memotivasi mahasiswa belajar, (d) RPS mengatur mekanisme untuk mengarahkan semua upaya dan fasilitas untuk memenuhi kebutuhan mahasiswa, (e) RPS memberikan kontribusi yang berarti untuk pembelajaran yang bermakna, serta (f) RPS yang berhasil dapat membantu mahasiswa belajar mandiri dan belajar sepanjang hayat.

Perlunya mengikutsertakan mahasiswa sejak awal merancang perkuliahan dikemukan oleh Boak (1998: 2-3), Toohey (2000: 17), dan Suciati (2001: 3) bahwa dalam mempelajari sesuatu, mahasiswa perlu diikutsertakan mulai dari awal, mengembangkan pertanyaan, mengenali pengetahuan awal dan halhal yang belum diketahui, mencoba menerapkan pengetahuan baru dalam menjawab pertanyaan dan memecahkan masalah. Dalam membahas konsep kontrak kuliah, didiskusikan deskripsi, tujuan, pokok bahasan, strategi pembelajaran, taat acara penilaian serta referensi yang digunakan. Buram awal RPS yang dibuat oleh dosen tentu mendorong mahasiswa bertanya, memberikan pendapat, serta menyampaikan harapan, keinginan, serta kebutuhannya.

Tidak jarang terjadi seperti yang dikemukakan oleh Hussey dan Smith (2010: 65 - 68), tujuan perkuliahan yang dirumuskan oleh dosen tidak dapat dijadikan acuan belajar bagi mahaiswa. Dapat jadi tujuan itu mengandung kompetensi yang terlalu umum atau sempit. Rumusan tujuan yang demikian mereduksi dan merusak proses pembelajaran. Akibat lain Suciati (2001: 1) menyebutkan, mahasiswa terkadang tidak mengetahui secara jelas tentang tujuan dan tata cara penyelenggaraan perkuliahan, sehingga menebak-nebak pengalaman belajar yang akan dijalani (Suciati, 2001: 1). Oleh karena itu, dosen perlu memperhatikan ketentuan menyusun RPS sehingga benar-benar dapat membantu mahasiswa dan dosen mewujudkan pembelajaran yang efektif dan efisien.

Kaitan RPS dengan prinsip-prinsip belajar, Boak (1998: 6) mengemukakan kembali argumentasi Malcolm Knowles (1986) yang mengatakan bahwa RPS sebagai kontrak kuliah berkaitan erat dengan prinsip-prinsip dasar belajar orang dewasa, khususnya (a) orang dewasa pada umumnya dapat dan ingin bertanggung jawab atas belajar, (b) setiap orang membawa aneka ragam pengalaman ke dalam proses belajar sehingga menjadi sumber belajar yang kaya, (c) orang dewasa lebih siap belajar apabila melihat relevansinya dengan kebutuhan dan keinginan, dan (d) setiap orang memiliki gaya dan kecepatan belajar yang unik dan juga memiliki komitmen, tujuan, serta motivasi yang unik.

Di samping membantu tugas dosen dengan membuat jelas kedudukan serta peranan mahasiswa dalam proses pembelajaran (Suciati, 2001: 3), Boak (1998: 4-5) menyebutkan manfaat RPS sebagai kontrak belajar/kuliah adalah (a) membuat belajar lebih relevan, (b) menjadikan mahasiswa berperan utama dalam menyempurnakan RPS, (c) pada umumnya memberikan motivasi belajar lebih besar kepada mahasiswa, (d) memberikan mekanisme untuk memfokuskan semua upaya dan sumber daya untuk memenuhi kebutuhan mahasiswa, (e) menjadikan relevansi belajar lebih luas, dan (f) membantu setiap mahasiswa mengembangkan keterampilan belajar mandiri dan terus belajar sesudah menyelesaikan kuliahnya.

Tidak jauh berbeda dengan manfaat RPS seperti yang dikemukakan Boak, dilihat dari isinya, Suciati (2001: 4) mengungkapkan RPS sebagai Kontrak Perkuliahan meningkatkan efisiensi belajar karena 
dalam bentuk lengkap berisi penjelasan secara garis besar pengalaman belajar setiap pertemuan. Dengan mengerti terlebih dahulu apa yang akan dibahas, mahasiswa memiliki kerangka berpikir untuk mencerna dan menanggapi apa yang akan dibahas dalam perkuliahan. Dari segi efektivitas, Suciati (2001: 5) berpendapat RPS sebagai kontrak perkuliahan merupakan cara yang paling efektif untuk membantu mahasiswa mendiagnosis kebutuhan belajar, merancang kegiatan belajar, mendefinisikan dan memilih bahan belajar yang relevan dan cara belajar yang tepat, serta menjadi terlatih untuk melakukan evaluasi pribadi.

RPS yang efektif menurut Boak (1998: 5) mempunyai dua karakteristik utama (a) flexibilitas, dan (b) fokus. Fleksibilitas ialah dapat memenuhi berbagai kebutuhan dan gaya belajar mahasiswa. Fokus ialah efektif membantu mahasiswa memfokuskan perhatiannya mencapai hasil dan capaian belajar tertentu/khusus. Kedua karakteristik utama ini diperlukan untuk suatu kontrak belajar efektif. Tanpa fleksibilitas, kebanyakan manfaat kontrak belajar tidak diperoleh. Tanpa fokus, mahasiswa mudah kehilangan arah.

Sebagai Kontrak Perkuliahan, buram awal RPS disusun oleh dosen yang bersangkutan memuat gambaran yang jelas dan rinci tentang deskripsi mata kuliah, tujuan perkuliahan, strategi, evaluasi dan kriteria yang digunakan. RPS dibahas dan disepakati dengan mahasiswa pada awal perkuliahan untuk menjadi kontrak kuliah dan acuan penyelenggaraan perkuliahan (Boak 1998: 2 \& Suciati 2001: 7). Dalam proses pembahasan buram RPS itu dimungkinkan terjadi negosiasi antara mahasiswa dengan dosen berkaitan dengan setiap aspek yang didiskripsikan dalam RPS. Dalam proses negosiasi tersebut, Boak (1998: 3) menyarankan agar (a) mahasiswa dan dosen berpegang teguh pada tujuan mata kuliah yang ditetapkan dalam kurikulum, (b) mahasiswa harus bersedia belajar, memberikan pendapat atas setiap komponen dalam rancangan RPS, (c) dosen bersedia mengubah pendekatan pembelajaran setelah mendengarkan, bertanya, dan membantu mahasiswa, dan (d) bila perlu dosen meminta bantuan pihak lain, misalnya ketua jurusan/program studi dalam melaksanakan perkuliahan.

Akan tetapi, berbagai informasi yang diperoleh dari beberapa mahasiswa Strata 1, 2, dan 3, beberapa mata kuliah tidak menggunakan RPS atau mahasiswa tidak menerima RPS. Ada dosen yang hanya memberikan silabus mata kuliah yang berisi jadwal pertemuan/perkuliahan, pokok bahasan dalam satu semester, dan daftar buku rujukan. Kalaupun ada dosen memberikan RPS kepada mahasiswa, tetapi tanpa melalui pembahasan dan kesepakatan bersama antara dosen dan mahasiswa. Lebih jauh lagi, dalam proses perkuliahan, tidak jarang pokok bahasan dan bahan perkuliahan tidak sesuai dengan silabus yang diterima mahasiswa pada awal semester.

Tidak tersedianya RPS mengakibatkan mahasiswa tidak mengetahui secara jelas deskripsi, tujuan, pokok bahasan mata kuliah serta kegiatan perkuliahan selama semester. Lebih buruk lagi, mahasiswa tidak mengetahui kompetensi dan manfaat yang akan diperoleh. Dengan demikian, peran serta dan keaktifan mahasiswa dalam perkuliahan akan rendah dan sulit dapat diharapkan mahasiswa giat dan tekun belajar. Akhirnya, target mahasiswa terbatas pada kelulusan saja, bukan untuk memperoleh ilmu dalam meningkatkan kompetensinya.

Sementara itu, cukup banyak juga dosen yang menyusun RPS dengan mengikutsertakan mahasiswa sehingga dari awal diketahui deskripsi, tujuan, pokok bahasan, strategi dan metode perkuliahan, serta tata acara penilaian dengan silabus yang lengkap sehingga mahasiswa mengetahui rencana kegiatan setiap pertemuan/perkuliahan. Akan tetapi, pengalaman peneliti menunjukkan, cukup banyak mahasiswa yang tidak menggunakan RPS itu sebagaimana seharusnya. Misalnya, mahasiswa tidak mempersiapkan diri dengan mempelajari di luar kelas pokok bahasan mengacu pada rujukan yang tertera pada silabus. Bahkan, sejumlah mahasiswa tidak mengetahui pokok bahasan dan rencana kegiatan sebelum masuk ke kelas mengikuti perkuliahan.

Tidak tersedianya RPS yang disepakati oleh dosen dan mahasiswa atau tersedianya RPS sebagaimana seharusnya tetapi tidak dipergunakan oleh mahasiswa mengakibatkan mahasiswa tidak mempersiapkan diri sebelum perkuliahan, tidak aktif dalam diskusi, serta tidak termotivasi belajar dan cenderung pasif. Keadaan yang demikian tentu membuat kualitas proses dan hasil perkuliahan tidak berkualitas serta tujuan mata kuliah tidak tercapai.

Tidak jarang juga, RPS dan SAP tidak dapat dijadikan pedoman untuk dosen dan mahasiswa dalam menyelenggarakan perkuliahan. Alasannya, pertama, disusun terlalu umum, tidak spesifik, dan tidak cukup operasional. Kedua, disusun terlalu sempit dan kaku sehingga tidak memberikan keluwesan kepada dosen dan mahasiswa melaksanakan perkuliahan secara kreatif dan menyenangkan. Pengalaman belajar yang demikian melemahkan motivasi mahasiswa belajar (Hussey \& Smith, 2010: 65). 
Oleh karena penting dan strategisnya kedudukan RPS dalam penyelenggaraan perkuliahan sehingga tercapai tujuan perkuliahan, perlu diketahui bagaimana penggunaan RPS dalam proses perkuliahan. Penelitian ini dilakukan di Fakultas Ilmu Pendidikan, Universitas Negeri Jakarta (FIP UNJ). Fakultas ini dipilih karena semua Prodi di FIP UNJ mempelajari ilmu pendidikan sehingga menarik untuk diketahu sejauh mana proses perkuliahannya menerapkan prinsip-prinsip pembelajaran yang antara lain penggunaan RPS. Masalah penggunaan RPS tersebut mencakup (a) ketersediaan, (b) tata acara penyusunan, (c) kesesuaian, dan (d) penggunaan RPS.

Sejak diterapkannya kurikulum berbasis KKNI di UNJ, FIP UNJ belum pernah melakukan penelitian tentang penggunaan RPS dalam proses pembelajaran oleh dosen dan mahasiswa. Oleh karena itu perlu dilakukan penelitian awal untuk memperoleh gambaran tentang pelaksanaan standar proses pembelajaran khususnya berkaitan dengan RPS atau istilah lain di FIP UNJ

Mengacu pada latar belakang masalah yang telah diuraikan, penelitian ini bertujuan untuk mengetahui penggunaan RPS dalam penyelenggaraan perkuliahan di FIP UNJ dan memberikan masukan kepada pimpinan, koordinator program studi, dosen, serta mahasiswa di lingkungan FIP UNJ bagaimana meningkatkan pemanfaatkan RPS untuk pencapaian tujuan mata kuliah secara optimal. Secara khusus, tujuan penelitian ini ialah untuk mengetahui (a) ketersediaan RPS setiap mata kuliah untuk mahasiswa dan dosen, (b) proses penyusunan RPS, (c) kesesuaian RPS untuk mencapai tujuan perkuliahan, dan (d) tata cara penggunaan RPS dalam proses perkuliahan.

Tujuan umum dan khusus penelitian ini dicapai dengan melakukan survei dan pengamatan di lingkungan FIP UNJ untuk memperoleh data dan informasi yang lengkap dan akurat. Mengacu pada tujuannya, penelitian ini termasuk penelitian deskriptif evaluatif dengan menggunakan data kualitatif dan kuantitatif.

Hasil penelitian studi kasus ini bermanfaat untuk meningkatkan mutu proses dan hasil perkuliahan melalui penggunaan RPS secara tepat guna dan berhasil guna. Di samping itu, rekomendasi hasil penelitian ini dapat dijadikan acuan bagi pimpinan dan koordinator prodi di lingkungan FIP UNJ untuk merumuskan kebijkan lebih lanjut tentang penggunaan RPS. Hasil penelitian kasus ini dapat dijadikan sebagai salah satu acuan dalam melakukan penelitian dengan ruang lingkup lebih luas di tingkat Fakultas dan Universitas di lingkungan UNJ.

\section{METODE PENELITIAN}

Tujuan umum penelitian ini ialah untuk mengetahui penggunaan RPS di FIP UNJ pada tahun 2017. Gambaran yang dimaksud mencakup acuan dalam menyusun RPS, ketersediaan RPS, peran serta mahasiswa dalam menyusun dan menetapkan RPS, serta pemanfaatan RPS dalam proses perkuliahan. Sumber data ialah mahasiswa FIP UNJ, tahun 2017 serta dokumen RPS. Data dikumpulkan dengan menggunakan kuesioner, wawancara, dan studi dokumen. Data diolah dan dianalisis dengan menggunakan statistik sederhana dan secara deskriptif.

\section{HASIL DAN PEMBAHASAN}

\section{Data Kuesioner}

Data kuesioner disebarkan ke tujuh program studi yang ada dalam Fakultas Ilmu Pendidikan Universitas Negeri Jakarta. Hal-hal yang ditanyakan dalam kuesioner yaitu mengenai penerimaan RPS untuk suatu mata kuliah, masukan untuk penyempurnaan RPS, manfaat RPS, dan proses pembelajaran. Untuk itu, ada 11 butir pernyataan kuesioner yang diberikan ke mahasiswa di setiap program studi.

\section{Penerimaan RPS}

Di dalam pernyataan penerimaan RPS, ada beberapa hal yang ditanyakan yaitu mahasiswa memperoleh RPS, waktu menerima RPS, dan sumber memperoleh RPS. Mahasiswa yang mendapat RPS paling banyak berada di prodi $\mathrm{BK}, \mathrm{TP}$, dan MP dari dua kelas yang diberikan kuesioner menjawab jika semua (100\%) mahasiswa memperoleh RPS. Di posisi kedua, mahasiswa prodi PAUD menjawab jika semua (100\%) mahasiswa dan hampir semua (97.61\%) mahasiswa memperoleh RPS. Di posisi ketiga, mahasiswa prodi PLS menjawab jika semua (100\%) mahasiswa dan hampir semua (97.61\%) mahasiswa memperoleh RPS. Di posisi keempat, mahasiswa prodi PGSD menjawab jika semua (100\%) mahasiswa dan sebagian besar (67.86\%) mahasiswa memperoleh RPS. Selain itu, dari beberapa program studi hampir semua memeproleh RPS di pertemuan pertama dan diperoleh dari dosen bersangkutan.

\section{Masukan tentang RPS}

Di dalam pernyataan masukan tentang RPS, ada beberapa hal yang ditanyakan yaitu dosen memberikan penjelasan tentang RPS, dosen meminta masukan dari mahasiswa, mahasiswa memberikan masukan untuk RPS, bagian yang diberikan masukan, serta dosen menyetujui masukan mahasiswa. Hampir 
semua mahasiswa di setiap program studi menjawab dosen memberikan penjelasan tentang RPS serta mahasiswa diberikan kesempatan untuk memberi masukan terhadap RPS yang telah dibuat dosen.

\section{Manfaat RPS}

Di dalam pernyataan manfaat RPS, ada beberapa hal yang ditanyakan yaitu tujuan penggunaan RPS oleh mahasiswa dan manfaat RPS. Hampir semua mahasiswa di setiap program studi memaparkan jika tujuan penggunaan RPS oleh mahasiswa untuk mempersiapkan bahan perkuliahan.

\section{Perkuliahan Mengacu pada RPS}

Hampir semua program studi sudah melaksanakan perkuliahan yang mengacu pada RPS sehingga dapat berlangsung secara sistematis dan terencana sesuai dengan kesepakatan yang telah dibuat dosen dan mahasiswa di kontrak perkuliahan atau RPS.

\section{Pokok bahasan untuk pertemuan hari ini}

Jika dilihat dari jawaban yang dituliskan oleh mahasiswa, hampir semua mahasiswa (76-99\%) dapat menuliskan pokok bahasan yang diajarkan oleh dosen sehingga dapat terlihat jika mahasiswa membaca RPS yang diberikan oleh dosen. Hal ini membuat mahasiswa dapat mempersiapkan diri untuk belajar sebelum perkuliahan dimulai.

\section{Rujukan/sumber bacaan hari ini}

Hampir semua (76-99\%) mahasiswa di dua mata kuliah dalam setiap program studi dapat menuliskan rujukan/sumber bacaan yang diajarkan sehingga mahasiswa tidak bingung dalam mencari rujukan/ sumber bacaan.

\section{Tujuan pembelajaran}

Sebagian besar (51-75\%) mahasiswa paham tentang rumusan tujuan pembelajaran perkuliahan, hanya sedikit sekali (1-26\%) yang tidak paham tentang tujuan pembelajaran. Tujuan pembelajaran dianggap mahasiswa sama dengan tujuan mahasiswa untuk kuliah.

\section{Pembuatan pertanyaan untuk dosen}

Hampir semua (76-99\%) mahasiswa tidak dapat membuat pertanyaan untuk dosen. Pernyataan ini dikosongkan atau tidak dijawab oleh mahasiswa.

\section{Studi Dokumen RPS}

Dari 14 mata kuliah di seluruh program studi Fakultas Ilmu Pendidikan hanya ada empat dosen yang mengumpulkan RPS. Selebihnya tidak mengumpulkan meskipun sudah diminta berkali-kali. Dari keempat dosen yang mengumpulkan, hanya ada satu dosen yang mengumpulkan RPS dan dilengkapi dengan satuan acara perkuliahan (SAP). RPS keempat dosen dilihat dari kurikulum sudah lengkap karena dosen sudah memuat kompetensi akhir dari mata kuliah yang diampu beserta kompetensi khusus dari setiap topik materi. Hanya satu dosen yang memiliki RPS sangat lengkap karena memuat capaian pembelajaran lulusan untuk sikap, pengetahuan, keterampilan umum, dan keterampilan khusus. Selain itu, juga disertakan capaian pembelajaran mata kuliah dan SAP.

Identitas awal RPS yang dibuat keempat dosen sudah dilengkapi dengan deskripsi mata kuliah, bobot/SKS mata kuliah, kode mata kuliah, semester, serta nama dosen pembina. RPS sudah memuat ataupun menjelaskan tentang perencanaan dan pelaksanaan kegiatan pembelajaran yang dilakukan selama satu semester. Hanya saja dari keempat dosen hanya satu dosen yang mencantumkan capaian pembelajaran lulusan sedangkan ketiga RPS nya lain tidak mencantumkan capaian pembelajaran lulusan sehingga tidak dapat diketahui kesesuaian antara kompetensi akhir mata kuliah dengan capaian pembelajaran lulusan.

Setelah menjelaskan identitas awal RPS, keempat dosen membuat tabel yang menjelaskan tentang tujuan perkuliahan; bahan kajian; metode pembelajaran; pengalaman belajar mahasiswa; penilaian yang memuat kriteria, indikator, dan bobot nilai; serta referensi sedangkan untuk jadwal perkuliahan tidak dicantumkan di dalam RPS.

\section{Pembahasan}

Pembelajaran merupakan sebuah sistem yang terdiri dari beberapa komponen seperti tujuan pembelajaran, peserta didik, pengajar, kurikulum, media dan metode pembelajaran, sampai pada evaluasi pembelajaran. Oleh karena itu, untuk menghasilkan pembelajaran yang efektif maka diperlukan penyusunan rencana pembelajaran semester (RPS) agar berlangsung secara sistematis dan bertujuan.

Tujuan pembelajaran menjadi suatu acuan yang dituju dalam suatu proses pembelajaran. Seluruh kegiatan pembelajaran mengarah pada keberhasilan pencapaian tujuan pembelajaran sehingga semua komponen pembelajaran mengarah pada ketercapaian tujuan tersebut. Menjadi tanggung jawab pendidik untuk dapat mengelola dan mengatur informasi bagi peserta didik seperti penyajian informasi, pemberian contoh, latihan, dan umpan balik (Reigeluth, 1983: 8). Hal ini menandakan jika pembelajaran dilakukan dengan unsur kesengajaan serta melalui perencanaan yang matang.

Brown (dalam Sanjaya, 2008:11) mengemukakan jika model pembelajaran hendaknya berfokus pada 
kebutuhan peserta didik untuk membantu dalam memahami sesuatu. RPS harus dibuat oleh setiap pendidik agar terselenggaranya pembelajaran yang efektif dan efisien. Fakultas Ilmu Pendidikan, Universitas Negeri Jakarta memiliki tujuh program studi yaitu Pendidikan Guru Sekolah Dasar, Teknologi Pendidikan, Pendidikan Anak Usia Dini, Pendidikan Luar Sekolah, Manajemen Pendidikan, Bimbingan Konseling, dan Pendidikan Luar Biasa.

Berdasarkan hasil kuesioner yang disebarkan di kedua mata kuliah pada setiap program studi di lingkungan FIP UNJ terlihat jika hampir semua dosen program studi sudah membagikan RPS ke mahasiswa. Hanya satu program studi di satu mata kuliah yang tidak membagikan RPS ke mahasiswa. Hal ini menandakan hanya sedikit sekali dosen yang tidak membuat RPS untuk mahasiswa. Dengan hampir semua dosen di program studi sudah membuat RPS dan menyerahkan ke mahasiswa maka pembelajaran menjadi lebih relevan, memotivasi mahasiswa untuk belajar, berfokus pada kebutuhan mahasiswa, menghadirkan pembelajaran yang bermakna, dan membantu mahasiswa agar dapat belajar mandiri dan sepanjang hayat (Boak, 1998: 1-5).

Sebagian besar dosen sudah memberikan RPS di pertemuan pertama karena RPS merupakan kontrak belajar/kuliah yang mengikat mahasiswa dan dosen selama satu semester meskipun bersifat fleksibel sehingga sebaiknya RPS diberikan di pertemuan pertama sebagai orientasi mata kuliah. Dalam pertemuan pertama tersebut, dosen dan mahasiswa membuat kesepakatan secara tertulis dan formal. Ketika membahas kontrak kuliah, dosen membahas deskripsi, tujuan, pokok bahasan, strategi pembelajaran, taat acara penilaian, serta referensi yang digunakan. Berdasarkan hasil penghitungan kuesioner, hampir semua dosen di setiap program studi sudah memberikan penjelasan tentang RPS.

Dalam pembahasan kontrak kuliah, mahasiswa dilibatkan dalam penyempurnaan RPS. Perlunya mengikutsertakan mahasiswa sejak awal merancang perkuliahan dikemukan oleh Boak (1998: 2-3), Toohey (2000: 17), dan Suciati (2001: 3) bahwa dalam mempelajari sesuatu, mahasiswa perlu diikutsertakan mulai dari awal, mengembangkan pertanyaan, mengenali pengetahuan awal dan hal-hal yang belum diketahui, mencoba menerapkan pengetahuan baru dalam menjawab pertanyaan, dan memecahkan masalah.

Hampir semua dosen di program studi sudah memberikan RPS secara langsung ke mahasiswa. Namun, penyusunan RPS oleh dosen belum melibatkan partisipasi mahasiswa. Dosen belum meminta masukan dari mahasiswa untuk RPS, Dosen masih bertindak secara individu di dalam menyusun RPS. Mahasiswa umumnya hanya mengikuti materi, metode, media, sampai pada evaluasi pembelajaran yang sudah ditetapkan dan dirancang oleh dosen bersangkutan. Hal ini tidak sejalan dengan prinsip belajar mahasiswa sebagai manusia dewasa yang diperlakukan sebagai pribadi yang bebas, bertanggung jawab, dan dapat dipercayai (Suciati, 2001: 3). Hasil penelitian yang dilakukan oleh Toohey (2009: 9 - 12) mengemukakan jika pendekatan belajar di pendidikan tinggi ada dua macam belajar yaitu mendalam dan superfisial. Jika ditelaah berdasarkan makna dua pendekatan belajar tersebut, dengan mahasiswa tidak dilibatkan dalam penyusunan dan kesepakatan RPS, pendekatan belajar superfisial yang terjadi. Pendekatan belajar superfisial membuat mahasiswa tertarik untuk memenuhi persyaratan sistem yang ada. Mahasiswa tidak diajak membangun pengetahuan secara bermakna dengan mendiskusikan topik-topik melalui strategi membaca banyak. Pendekatan belajar superfisial membuat mahasiswa menghapal dan mengungkapkan kembali informasi yang telah dihapal untuk sekedar memenuhi persyaratan penilaian. Hasil belajar pun tidak bertahan lama dan mudah sekali dilupakan oleh mahasiswa. Kemampuan kognitif hanya berlangsung pada kawasan kognitif yang rendah.

Ketika pernyataan kuesioner berisi tentang bagian mahasiswa untuk memberikan masukan RPS, sebagian besar mahasiswa memilih tidak menjawab karena tidak dibiasakan oleh dosen untuk memberikan masukan di RPS. Begitupula ketika pernyataan dosen menyetujui masukan dari mahasiswa untuk RPS, mahasiswa memilih tidak menjawab. Padahal, sebagian besar mahasiswa menjawab jika RPS bermanfaat untuk mempersiapkan bahan perkuliahan dan mempelajari pokok bahasan sebelum perkuliahan selama satu semester. Ketepatan dosen dalam konsisten dengan RPS bagi sebagian besar mahasiswa menjelaskan selalu tepat dan kadang-kadang. Jadi, tidak selamanya dosen selalu sesuai dengan RPS yang dibuat.

Mahasiswa sudah mengetahui pokok bahasan yang mau dibelajarkan oleh dosen begitupula dengan rujukan/sumber bacaan dan tujuan pembelajaran. Tetapi mahasiswa tidak mampu membuat pertanyaan untuk dosen. Hal ini dikarenakan mahasiswa tidak dibiasakan untuk memberikan masukan topik di awal perkuliahan sehingga terbiasa diberi oleh dosen dan tidak memberi. Kemampuan berpikir kritis dan kreatif 
dalam tatanan berpikir tingkat tinggi belum dikuasai dengan baik oleh mahasiswa. Hal ini menandakan bahwa interaksi komunikasi antara dosen dengan mahasiswa dalam penyusunan RPS sangat membantu di dalam mencapai belajar yang bermakna. Tentunya jika mahasiswa dibiasakan untuk berdiskusi tentang topik materi, kemampuan berpikir kritis dan kreatif akan terlatih.

Merujuk pendapat Knowles (1990), Evans dan Nation (2000:148) mengemukakan, karakteristik mahasiswa sebagai pemelajar orang dewasa: (a) termotivasi terutama oleh faktor-faktor interinsik dan terdorong untuk mengarahkan semua tenaganya untuk meningkatkan kualitas hidupnya serta memperkuat aktualisasi diri/self-esteem; (b) cenderung berpusat pada masalah atau tugas yang dihadapi; (c) mengintegerasikan informasi/pengetahuan baru paling efektif dengan konteks situasi kehidupan nyata; (d) memasuki situasi belajar dengan pengalaman hidup yang banyak; sering khawatir kehilangan aktualisasi diri (self-esteem) di kelas; (e) memiliki perasaan yang kuat bagaimana sesorang belajar dan mampu mempraktikkan pengaturan diri (self regulation) yang tinggi dalam proses belajar. Mahasiswa sebaiknya dilibatkan dalam penyusunan materi RPS sehingga terbiasa membaca banyak sumber belajar dan membuat belajar menjadi kegiatan yang bermakna.

Sesuai ketentuan dalam peraturan pemerintah No. 19 Tahun 2005 tentang Standar Nasional Pendidikan maka pelaksanaan pembelajaran di semua jenjang pendidikan termasuk perguruan tinggi diharapkan diselenggarakan secara interaktif, inspiratif, menyenangkan, menantang, memotivasi peserta didik untuk berpartisipasi aktif, serta memberikan ruang yang cukup bagi prakarsa, kreativitas, dan kemandirian sesuai bakat, minat, dan perkembangan fisik serta psikologis peserta didik sehingga memberikan mahasiswa kesempatan dalam berdiskusi sangat membantu dalam mengkonstruksi berpikir kritis mahasiswa.

Dengan mahasiswa ditugaskan membuat pertanyaan ke dosen sebenarnya salah satu bentuk umpan balik yang dapat dilakukan oleh dosen untuk meningkatkan kualitas pembelajaran. Umpan balik dapat dianggap sebagai bahan evaluasi setiap dosen dalam melaksanakan proses pembelajaran.

Jika dilihat dari kompetensi desain pembelajaran yang dimiliki oleh dosen sudah sangat baik. Hal ini terlihat dari RPS yang dibuat sudah berisi serangkaian kompetensi, materi pembelajaran, metode pembelajaran, sampai evaluasi hasil belajar yang nantinya digunakan untuk mengukur kemampuan mahasiswa. Secara keseluruhan, kegiatan pembelajaran yang dituangkan di dalam RPS sudah mewadahi mahasiswa untuk belajar secara aktif. Beragam strategi dan metode pembelajaran dilakukan oleh guru.

Dengan demikian, berdasarkan hasil kuesioner dan studi dokumen yang dilakukan dapat disimpulkan jika sebagian besar dosen di lingkungan Fakultas Ilmu Pendidikan Universitas Negeri Jakarta sudah membuat RPS dan memberikan ke mahasiswa. Namun, masih ditemukan jika dosen tidak selalu memberikan kesempatan bagi mahasiswa untuk memberikan masukan tentang topik-topik yang ada di RPS. Kemampuan dosen dalam membuat RPS sudah baik terlihat dari RPS yang dibuat meskipun belum mencantumkan capaian pembelajaran lulusan sehingga tidak bisa dilihat kesesuaiannya dengan kompetensi mata kuliah.

\section{PENUTUP}

\section{Kesimpulan}

Dosen sudah membiasakan membuat RPS di awal perkuliahan pada pertemuan pertama dan membagikan langsung ke mahasiswa. Hal ini memberikan dampak positif bagi mahasiswa yaitu jadi tahu topik bahasan yang mau dibelajarkan, rujuan/sumber bacaan yang digunakan, serta tujuan pembelajaran dari perkuliahan yang berlangsung. Tetapi, ketika membuat RPS, dosen tidak melibatkan mahasiswa untuk berdiskusi sehinggga mahasiswa tidak terlatih dalam berpikir kreatif dan kritis dan berimbas pada mahasiswa tidak terbiasa dalam memberikan pertanyaan untuk dosen.

RPS yang dibuat oleh dosen sudah dapat mengakomodir mahasiswa untuk belajar secara aktif dan mandiri. RPS sudah lengkap memuat komponenkomponen seperti kompetensi, deskripsi mata kuliah, bobot SKS, dosen pengampu, topik materi, pengalaman belajar, media pembelajaran, sumber belajar, sampai pada kriteria evaluasi yang digunakan.

\section{Saran}

Dosen sebaiknya berdiskusi dengan mahasiswa untuk membahas topik-topik yang ada di dalam RPS sehingga mahasiswa jadi lebih banyak membaca berbagai macam sumber belajar di dalam memberikan saran. Mahasiswa nantinya menjadi pebelajar yang aktif dalam memproses dan mengolah informasi sehingga keterampilan berpikir kreatif dan kritis dapat terlatih dengan baik.

Fakultas ataupun program studi memiliki arsip RPS dari dosen sehingga ketika RPS dibutuhkan tidak perlu datang ke dosen yang bersangkutan 
tetapi dapat langsung mengambil di program studi. Keterbukaan dan masukan dari RPS yang dibuat oleh dosen sebagai penyempurnaan kegiatan pembelajaran yang dilakukan.

\section{DAFTAR PUSTAKA}

Boak, G. (1998). A complete guide to learning contract. Aldershot: Gower.

Evans, T. \& Nation, D. (2000). Changing university teaching: Reflection on creating educational technology. London: Kogan Page.

Harvey, L. \& Knight, P.T. (1996). Transforming higher education. Buckingham: SRHE and University Press.

Hussey, T. \& Smith, P. (2010). The trouble with higher education: A critical examination of our universities. New York: Routledge.

McNeil, J.D. (1996). Curriculum: A comprehensive in- troduction. New York: HarperCollins College Publishers.

Reigeluth, M. C. (1983). Instructional-design theories and models, An overview of their current status. New jersey: London.

Sanjaya, W. (2009). Strategi pembelajaran berorientasi standar proses pendidikan. Jakarta: Prenada

Shattock, M. (2004). Managing successful universities. Berkshire: SRHE and University Press.

Suciati. (2001). Kontrak perkuliahan. Jakarta: PAUPPAI-UT.

Tyler, R.W. (1949). Basic principles of curriculum and instruction. Chicago: The University of Chicago Press.

Permendikbud No 49 Tahun 2014

Permenristekdikti No 13 Tahun 2015

Permenristekdikti No 44 Tahun 2015

Peraturan pemerintah No 19 Tahun 2005 